Available online at http://iddtonline.info RESEARCHARTICLE

\title{
SCREENING OF INDIAN HERBS FOR HAEMOSTATIC ACTIVITY
}

\author{
${ }^{*}$ Jadhav Shital ${ }^{1}$, Kulkarni Chitrarekha ${ }^{1}$, Salunkhe Satyajeet ${ }^{1}$, Deshpande Adwait ${ }^{2}$, Bhise Satish ${ }^{2}$ \\ ${ }^{1}$ Government College of Pharmacy, Vidyanagar Karad 415124 \\ ${ }^{2}$ Sinhagad Institute of Pharmaceutical Sciences, Kusgaon (bk), Lonavala 410401 \\ *Email for correspondence: shitaljadhav67yahoo.com
}

\begin{abstract}
:
India is one of the important widespread geographic locations on mega biodiversity areas on earth. The rich cultural heritage of India is also associated with the use of available ethno medicinal flora and fauna since ages. To raise this traditional knowledge to global level and to serve the mankind using the same, a systematic modern approach has been adopted here to ascertain the rational use of traditionally applied Indian herbs for the purpose of healing wounds and controlling haemorrhage from cuts and bruises. In vitro clotting time of blood in presence and absence of various plant extracts was used as a guide to study haemostatic activityof the herbs under study. Of the ten plants evaluated, aqueous extracts of Quercus pubescens, Thevetia peruviana proved to have significant haemostatic activity at $\mathrm{P}<0.05$ as judged by Chi Square goodness of fit test, whereas alcoholic extracts of Zingiber officinale, Zanthoxylum rhetsa and petroleum ether extracts of Psidum guajava, Terminalia chebula, Zanthoxylum rhetsa confirmed the same results.
\end{abstract}

Keywords: Haemostatic, Indian herbs, Clotting time, Ehno medicine

\section{INTRODUCTION:}

In the current era of globalization and intellectual property rights India's folk knowledge of traditional remedies needs to be documented systematically ${ }^{1}$. Since 1978, WHO has developed a gobal classification of traditional medicine and pharmacological properties of several plant extracts have been demonstrated thereafter ${ }^{2}$. However many plants and their pharmacological activities remain unexplored ${ }^{3}$. Also antibacterial, antifungal antiinfective and anti-inflammatory activity are the most popular amongst scientists. ${ }^{4}$ In the present study 10 Indian herbs that are traditionally used by the Indian tribals to heal the wounds, and check the bleeding from cuts and bruises are screened for their haemostatic activity. It is a crucial time to study systematically and standardise procedure, dosage utilised and rationalisation of utility involved in traditional medicines ${ }^{5}$. Considering a need of taking ethnomedicinal knowledge to global level and identification of efficient haemostatitc agents to improve the management of bledding in various cases this study was undertaken. The study aims to evaluate in vitro haemostatic properties of aqueous and organic extracts of 10 selected plants and applying statistical approach to confirm the same.

\section{MATERIALS AND METHODS:}

\section{Collection and identification of Plants:}

Information regarding vernacular name, plant parts used, etc. was collected and authentic identification of plants was done with the help of different flora and monographs $6-20$

\section{Extraction Procedure:}

Plant parts (Refer table 1) were air dried and reduced to fine powder in a pulveriser. Aqueous, Alcoholic and Petroleum ether extracts of respective plant parts were concentrated $^{21}$.

\section{Evaluation of haemostatic activity:}

As a guide to study the haemostatic activity of various herbs and their parts, clotting time of blood in presence of various extracts of respective plant was determined in vitro using Lee White's Method as follows $^{22}$ :

Human venous blood was collected in a clean dry and corning glass tube. Clotting time determination in presence and absence of various extracts was determined and compared.

Hundred milligrams of concentrated solvent free extract was suspended in distilled water and final volume was made to $0.5 \mathrm{ml}$. This extract preparation was used in experimental sets. One millilitre of freshly withdrawn human venous blood was taken in a clean, grease and detergent free corning glass tube of $1 \mathrm{~cm}$ diameter containing $0.5 \mathrm{ml}$ of various extract preparations. Control determination was performed using $0.5 \mathrm{ml}$ of distilled water instead of extract preparation.

Statistical Analysis: Statistical significance of presented data was analysed by ' CChi Square test' at $\mathrm{P}<0.05^{23,24}$. 
Table 1: Indian herbs and their parts under current study

\begin{tabular}{|c|c|c|c|}
\hline Sr.no & Plant Names & Vernacular Name & Part used \\
\hline 1 & Eugenia jambolana & Jambhul & Bark \\
\hline 2 & Quercus pubescens & Majuphal(Maayaphala) & Seeds \\
\hline 3 & Plantago ovata & Isabgol & Seeds \\
\hline 4 & Moringa oleifera & Shevga & Leaves \\
\hline 5 & Psidium guajava & Peru & Rhizome \\
\hline 6 & Zingiber officinale & Adrak & Fruit \\
\hline 7 & Terminalia chebula & Hirda(Haritaki) & Latex \\
\hline 8 & Thevetia peruviana & Bitti & Fruit \\
\hline 9 & Zanthoxylum rhetsa & Teerphal & Leaves \\
\hline 10 & Vinca rosea & Sadaphuli & \\
\hline
\end{tabular}

\section{RESULTS AND DISCUSSION:}

Indian forests are rich in flora and fauna and are famous for the medicinal plants growing there. The tribals usually depend on the natural flora found around them for treating various ailments. The knowledge gained about the efficacy of medicinal plants by the tribes is however kept as a secret for generations together and is orally communicated to their descendents. The knowledge on the uses of medicinal plants leads to open up various ways for effective utilization of herbal medicines to all. Rationalization of medicinal uses of plants also requires a systematic study in this regard.

An attempt is made in this study to evaluate haemostatic activity of various extracts of Indian herbs. Among Aqueous, Ethanolic and Petroleum ether extracts of 10 herbs, namely Eugenia jambolana, Quercus pubescens, Plantago ovata, Moringa oleifera, Psidium guajava, Zingiber officinale, Terminalia chebula, Thevetia peruviana, Zanthoxylum rhetsa, , Vinca rosea, aqueous extract of latex of Thevetia peruviana showed the highest haemostatic activity showing $39.38 \%$ reduction in clotting time compared to control. Aqueous extract of fruits of Quercus pubescens proved to be the next best, showing $34.89 \%$ activity difference (Refer table no.2, figure no.1).
In the alcoholic extract group Zanthoxylum rhetsa, Zingiber officinale and Eugenia jambolana had substantial haemostatic activity with \% activity difference of 29.53 , 27.26 and 9.92 respectively (Refer table no.2, figure no.2). Petroleum ether extracts of various plants also showed considerable potential of haemostatic activity. The best among them were from extracts of Terminalia chebula and Zanthoxylum rhetsa which could bring about an increase in haemostatic activity around $21 \%$ as compared to control (Refer table no.2, figure no.3). Similar extract preparation of Psidium guajava, Zingiber officinale had shown substantial decrease in clotting time with $\%$ activity difference ranging from 4 to $16 \%$ ( Refer table no.2, figure no.3).

'Chi Square goodness of fit test' was applied to check statistical significance of screened herbs for their haemostatic activity ${ }^{(23,24)}$. Statistical analysis revealed that aqueous extracts of Quercus pubescens, Thevetia peruviana are found to be significant at $\mathrm{P}<0.05$. However alcoholic extracts of Zingiber officinale, Zanthoxylum rhetsa and petroleum ether extracts of Psidum guajava, Terminalia chebula, Zanthoxylum rhetsa also showed the same statistical findings.

Table 2: Clotting time determination in presence of various extracts of Indian medicinal herbs

\begin{tabular}{|c|l|l|l|l|l|}
\hline \multirow{2}{*}{ Sr.no } & \multicolumn{1}{|c|}{ Plant Names } & \multicolumn{4}{|c|}{ Clotting Time ( In Seconds) } \\
\cline { 3 - 6 } & & \multicolumn{1}{|c|}{ Control } & \multicolumn{1}{c|}{$\begin{array}{c}\text { Aqueuous } \\
\text { extract }\end{array}$} & $\begin{array}{c}\text { Alcoholic } \\
\text { extract }\end{array}$ & $\begin{array}{c}\text { Petroleum ether } \\
\text { extract }\end{array}$ \\
\hline 1 & Eugenia jambolana & $289 \pm 4.04$ & $289<$ & $260 \pm 1$ & $289<$ \\
\hline 2 & Quercus pubescens & $321 \pm 1.15$ & $209 \pm 0.57$ & $321 \pm 0.57$ & $307 \pm 1$ \\
\hline 3 & Plantago ovata & $306 \pm 0.57$ & $294 \pm 0.57$ & $306<$ & $306<$ \\
\hline 4 & Moringa oleifera & $263 \pm 0.57$ & $263<$ & $263<$ & $263<$ \\
\hline 5 & Psidium guajava & $392 \pm 1$ & $390 \pm 0.57$ & $393 \pm 2.30$ & $329 \pm 1.15$ \\
\hline 6 & Zingiber officinale & $408 \pm 0.57$ & $408<$ & $297 \pm 1$ & $355 \pm 0.57$ \\
\hline 7 & Terminalia chebula & $280 \pm 1.52$ & $280<$ & $280<$ & $222 \pm 2.08$ \\
\hline 8 & Thevetia peruviana & $320 \pm 0.57$ & $194 \pm 0.7$ & $320<$ & $320<$ \\
\hline 9 & Zanthoxylum rhetsa & $286 \pm 0.58$ & $251 \pm 0.57$ & $202 \pm 0.58$ & $229 \pm 1.15$ \\
\hline 10 & Vinca rosea & $325 \pm 0.57$ & $310 \pm 0.58$ & $325<$ & $325<$ \\
\hline
\end{tabular}




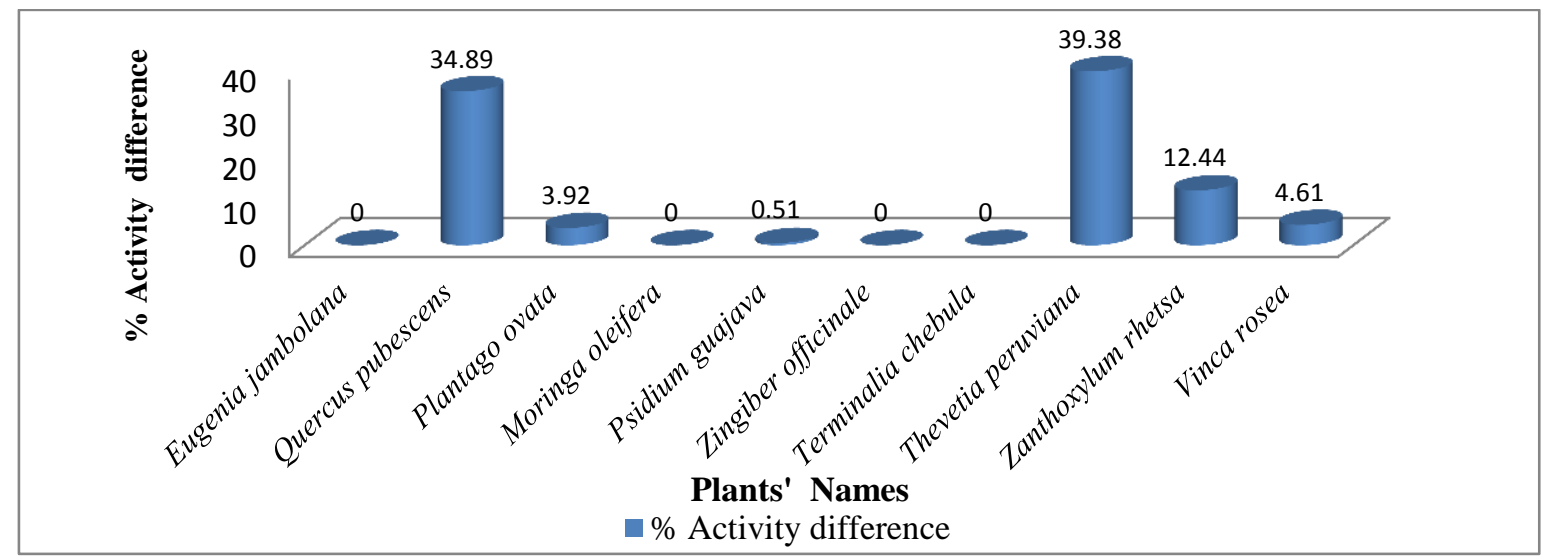

Figure 1: Graph showing \% haemostatic activity differences in presence of aqueous extract preparations compared to control set.

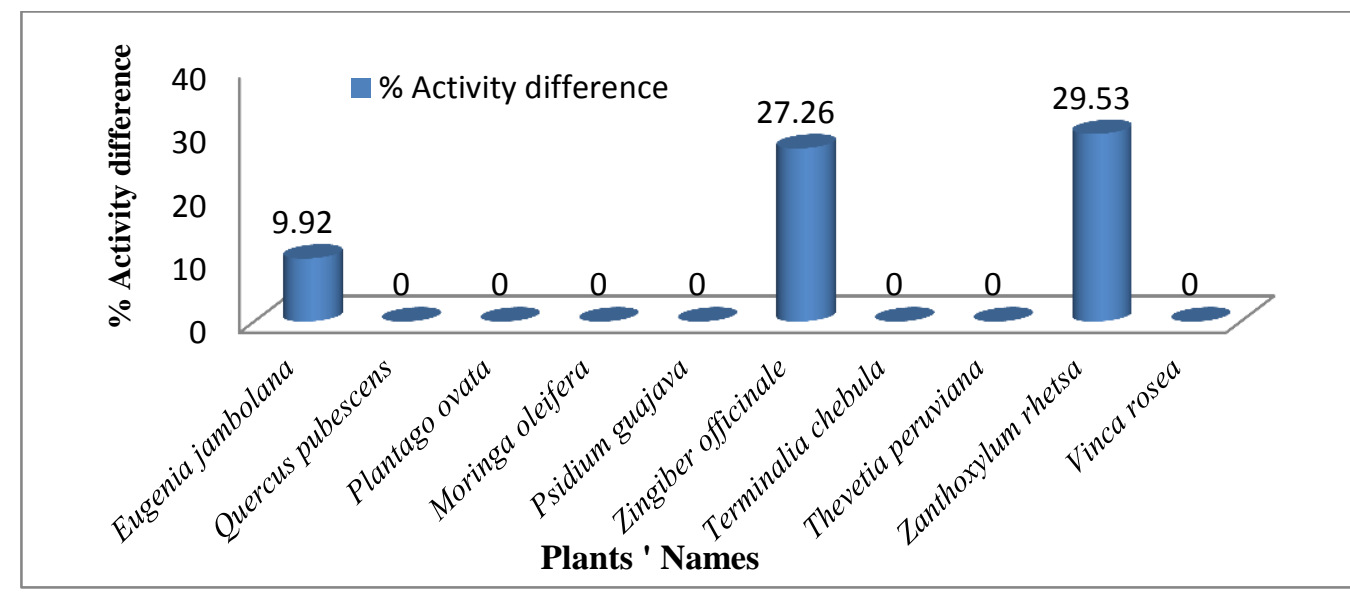

Figure 2: Graph showing \% haemostatic activity differences in presence of alcoholic extract preparations compared to control set.

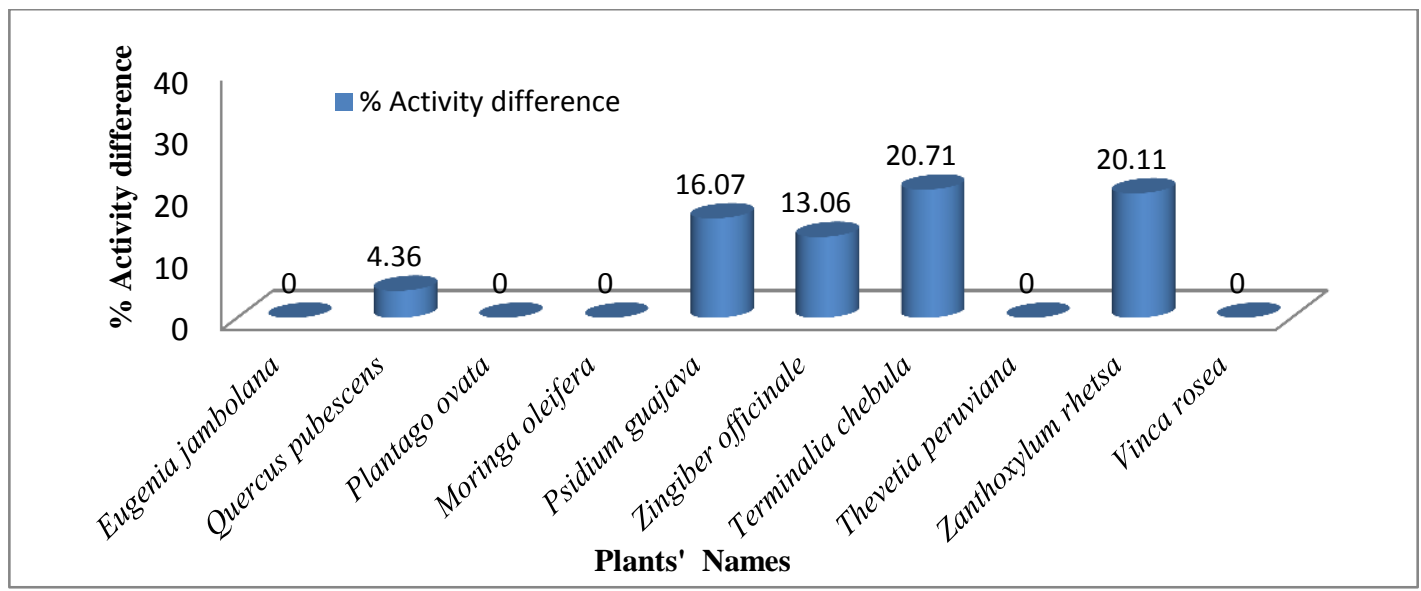

Figure 3: Graph showing \% haemostatic activity differences in presence of petroleum ether extract preparations compared to control set.

\section{CONCLUSION:}

Traditional herbal medicines deserve special appreciation with the outcome coming from several studies that were performed on ethno medicinal plants all over the world ${ }^{(25-29)}$. This results in the production of improvised drugs. The current study undertaken certainly revealed the haemostatic ability of Thevetia peruviana, Quercus pubescens, Zanthoxylum rhetsa,Zingiber officinale
Terminalia chebula, Psidium guajava, Eugenia jambolana, Vinca rosea and Plantago ovata thus justifying their perspective candidature for further studies to come up with future generation haemostatic medicine.

\section{ACKNOWLEDGEMENTS:}

Authors are thankful to all who helped us for this study directly or indirectly. 


\section{REFERENCES:}

1. Kulkarni CG, Deshpande AM, Folk therapies of Katkaris from Maharashtra, IJTK, 2011, 10(3), 554-558.

2. Organisation Mondiale de la Sante-OMS. Strategie de 1' OMS pour la Medecine Traditionnlle. OMS Geneve; 2010.P.65.

3. Dougnon TV, Klotoe JR, Dougnon TJ, Segbo J, Ategbo JM, Edorh P, Sodipo O, Dougnon F, Dandjesso C, Loko F, Dramane K,APJTD,2012,S927-S932.

4. Dossevi ML, Flenon JA, La Pharmacopee et la medicine traditionnelle au service du development sanitaire au Benin. Colloque UAC,2007, P. 334-335.

5. Mehta JH, Kulkarni CG, Jadhav ST, Deshpande AM, Bhise SB, Evaluation of Indian herbs for haemostatic activity, accepted for publication in IJRPC,2013,3(4).

6. Hooker JD. The flora of British India. Vols 1-7, L.Reeve and Co. Ltd. Kent. P.1872-1897.

7. Sharma BD, Balakrishnan NP and Sanjappa M. Flora of India. BSI Calcutta. Vol II.New Delhi:Deep printers, 1993

8. Sharma BD and Sanjappa M, Flora of India.BSI Calcutta. Deep Printers New Delhi. 1993; Vol III.

9. Nadkarni AK. Indian Materia Medica. $3^{\text {rd }}$ ed. Bombay: Popular Prakashan ,1954.

10. International Library Association. Medicinal plants sourcebook, India. International Library Association, Switzerland. 1996.

11. Wilson DE and Reeder DM. Mannual species of the World. Johns Hopkin University press. $3^{\text {rd }}$ ed, 2005

12. Bhattacharjee SK and De LC. Medicinal Herbs and Flowers. Avishkar publishers, Jaipur India.2005.

13. Small Indian civet- Viverricula indica http:// www.vietlinh.vn/langviet/toilamnd/cogni/khac/cyhuong_muskcat .html.October 20,2008.

14. Ziziphus xylopyrus. http:// zipcodezoo.com/Plants/Z/Ziziphus_ xylopyrus/.October 20,2008.

15. Nadkarni AK. Indian Materia Medica. Popular Prakashan Bombay.1954; $3^{\text {rd }}$ Edn: Vol.II.

16. Indrajao- Flowers of India. http:// www. Flowers of india.net/catalog/slides/Indrajao.html. October 20, 2008.
17. Wilson DE and Reeder DM, Mammal species of the world- A Taxonomic and Geographic Reference. $3^{\text {rd }}$ ed. Johns Hopkins University Press. 2005.

18. Blepharis-

Wikispecies.http://species.wikimedia.org/wiki/Blepharis. October 20, 2008.

19. Whitaker R. Common Indian Snakes- A Field Guide.1987.

20. Medicinal Plants of Tamil Nadu. http:// envis.frlht.org.in/checklist/TN.pdf. October 20, 2008.

21. Harbone JB. Phytochemical Methods- A Guide to Modern Techniques of plant analysis. $2^{\text {nd }}$ ed, Lodon: Champman and hall Ltd,1984. P.11-12.

22. Godkar PB and Godkar DP.Textbook of Medical Laboratory Technology. $2^{\text {nd }}$ ed. Bhalani Publishing House; 2006. P.109.

23. Bolton S and Bon C. Pharmaceutical Statistics Practical and Clinical Applications. $5^{\text {th }}$ ed. USA: Informa Health care, 2010. P.114-117.

24. Chap T. Le. Introductory Biostatistics. John Wiley and Son's Publication.2003:213-226.

25. Fozia F, Rai M,Tiwari A and Khan AA. Medicinal properties of Moringa oleifera: an overview of promising healer, JMPR,2012, 6(27), 4368-4374.

26. Shatoor AS. Cardio-tonic effect of the aqueous extract of whole plant of Crataegus aronica syn: azarolus (L) on isolated rabbit's heart, AJPP, 2012, 6(26), 1901-1909.

27. Fagbohun ED, Faleye OS. Effect of storage on chemical compostition and mycoflora of okra (Abelmoschus esculentus), International of Bioscence, 2012, 2(7), 83-89.

28. Jakkulwar AM, Wadhai VS. In vitro propagation of Chlorophytum borivilianum (Safed musli) and its root regeneration, IJCR, 2012, 4(5), 95-97.

29. Jeyaseelan EC, Jenothiny S, Pathmanathan MK, Jeyadevan JP. Antibacterial activity of sequentially extracted organic solvent extracts of fruits,flowers and leaves of Lawsonia inermis L.from Jaffna. APJTB, 2012, 2(10), 798-802. 